\title{
Why lawyers internationalize and police transnationalize: disjointed criminal justice at the border of the state
}

\author{
Mikkel Jarle Christensen ${ }^{1}$ iD
}

Accepted: 12 April 2021 /Published online: 5 August 2021

(C) The Author(s) 2021

\begin{abstract}
This article investigates the socio-genesis of two different types of criminal justice developed at the border of the state. At this border, the field of international criminal justice was differentiated from the field of transnational criminal justice. The article analyzes how elites of these two fields are characterized by distinct relations to the state that structure their ability to affect criminal justice outside of the national context. These professionals worked in parallel in national systems of justice where they accumulated distinct patterns of expertise and access to the state. On the basis of these socio-professional differences, law and police professionals helped define new criminal justice initiatives at the border of the state that deepened the division between them. The development of international criminal justice was dominated by professionals of law whereas transnational criminal justice was built primarily around police professionals. Societal responses to globalized crime are structured by this disjointed space of criminal justice in which legal and police professionals dominate distinct enforcement initiatives.
\end{abstract}

\section{Introduction}

Globalization has affected patterns of crime as well as the development of criminal justice initiatives designed to deal with illegality [1]. As globalization expanded and deepened, criminal justice responses to different types of criminality have taken distinct paths. Most significantly, states agreed to make certain crimes the object of international enforcement mandated to internationalized criminal courts and, often in parallel, negotiated other legal frameworks that left enforcement up to the states themselves. This has created two distinct systems often referred to as international and transnational criminal law [2]. This bifurcation is deeply consequential for

Mikkel Jarle Christensen

mjc@jur.ku.dk

1 iCourts (Danish National Research Foundation's Centre of Excellence for International Courts), Faculty of Law, University of Copenhagen, Karen Blixens Plads 16, DK-2300 Copenhagen S, Denmark 
contemporary responses to serious crimes that have massive human and economic effects across states and, arguably, affect global peace and security. The present article contributes an empirically informed analysis of the social dynamics behind the bifurcated fight against serious crimes of global concern.

Socio-legal scholars have highlighted the different professional dynamics of these two fields: International criminal justice has been dominated by law and lawyers, whereas transnational criminal justice has been dominated by police and other security agents $[3,4]$. Inspired by this perspective, and building on original data on more than 200 elite trajectories of lawyers and police officers working at the borders of the state, this article contributes a critical analysis of the socio-professional dynamics embedded and active in the bifurcation of international and transnational criminal justice seen here as ideal typical enforcement systems. The focus on agents active at the border of the state follows Max Weber's sociological concept of law. For Weber, the concept of law hinges on the presence of a staff engaged in enforcement ([5], pp. 34-35). Following this definition, the analysis shows how the activities of professionals at the border of the state were structured by their distinct positionalities within the state where legal and police professionals had different roles. This relational positionality formatted their accumulation of professional expertise and access to different forms of power that could be activated at the border of the state. Reconnecting elite agents to expertise built in the state, but also invested outside of it, the article investigates the role of these professionals in the development of the relatively distinct fields of international and transnational criminal justice. In global space, law and police were, to a certain extent, disjointed from each other.

The paper is organized in five sections. The first section critically surveys the relevant literature and develops the conceptual framework of the article. The second section presents the empirical material of the article - career trajectories of professionals in the two fields - and analyses their entanglements at the national level. The third section studies the internationalization of criminal justice, embedded in and influenced by legal elites, that took speed after the end of the Cold War and led, among other developments, to the creation of the first permanent International Criminal Court (ICC). The fourth section investigates the transnationalization of police organizations aimed at crafting new ways of responding to cross-border crime, influenced in particular by police professionals and perspectives. The fifth and concluding section contextualizes the findings of the article and draws out more heuristic perspectives, highlighting in particular potential future studies and takeaways of reconnecting internationalized elites to the national context.

\section{Theory and method}

The bifurcation of international and transnational criminal law has been conceptualized by a legal scholarship that is itself bifurcated. In other words, the market of legal scholarship seems to have been differentiated in parallel to its attempt at conceptualizing the differences between international and transnational criminal law. A subfield of research has specialized in 'international criminal law' and the crimes adjudicated by internationalized criminal courts and tribunals (genocide, crimes 
against humanity, war crimes and the crime of aggression [6, 7]). Another subfield focuses on what has been conceptualized as 'transnational criminal law' a domain focused on crimes, including terrorism, corruption and drug trafficking, the enforcement of which has remained the primary prerogative of the state and its criminal justice system $[8,9]$. The distinction between the two fields is often perceived to be based on their institutionalized functions, themselves seen as a result of state preferences about which crimes were best suited for international or, conversely, national enforcement. This perception is tied to the perceived goals of the two fields, international criminal law seen as targeting crimes typically perpetrated by the state or state entities whereas transnational criminal law is perceived to deal with crimes most frequently perpetrated by private individuals or entities.

This differentiation between international and transnational criminal justice built on specific historical developments. The negotiating histories of the internationalized criminal courts demonstrate that this differentiation was not a given. The 1937 treaty of what would have become the first international criminal court focused on terrorism [10]. Half a century later, negotiations for what became the ICC formally began with a 1989 proposal to establish a court for drug trafficking [11]. When the Rome Statute was passed in 1998, however, the ICC had subject-matter jurisdiction over so called core international crimes (the crime of aggression being added in 2017 [12]). In addition to this history, efforts still exist that aim to expand the jurisdiction of the ICC to include other crimes, or to establish new internationalized courts to deal with crimes currently perceived to belong to transnational criminal justice $[13,14]$. The sometimes porous borders between international and transnational criminal justice have previously been the object of scholarly attention [15]. In this context, scholars have been critical of what they perceive as a rigid distinction that reifies international and transnational criminal justice, calling instead for conceptions that allow for empirical studies of these fields [16]. In this context, researchers have underlined that the distinction between the two has little doctrinal or jurisprudential support, and that that it has a weak basis in criminological theories or empirical evidence of how crime actually unfolds [17, 18].

Outside of critical scholarship, practitioners also seem to have become increasingly aware of linkages between different types of serious, extra-national crime. In the field of international criminal justice, the ICC's Office of the Prosecutor (OTP) has highlighted the need to work with authorities dealing with crimes outside of its mandate [19]. Some overlaps already do exist. In the field of transnational criminal justice dominated by police cooperation, for instance, Interpol counts the crimes normally organized under international criminal law as one of its 17 areas of focus [20]. Other organizations exist where the lines of division between legal and police professionals are less clear. Such organizations include, for instance, the Council of Europe's Group of States against Corruption (GRECO) and the Intelligence College of Europe (ICE) where legal and police professionals work closely together also with other professional groups. In addition, some police work does takes place at the international level of state cooperation, for instance in relation to peacebuilding. Despite these overlaps, a lot of scholarship has reproduced the distinction between international and transnational criminal justice. 
Social science perspectives on the globalization of criminal justice initiatives also typically focus on one of these categories. Such studies have relied, for instance, on social network theory [21] to investigate how different stakeholders, including NGOs, affected policy building [22]. Such perspectives have also been used to analyze the creation of international criminal courts [23, 24] and how the diffusion and entrenchment of specific 'global prohibition regimes' or 'transnational legal orders' affected the fight against transnational crime [25, 26]. Scholars of transnational crime suppression often zoomed in on cooperation between police professionals [27], underlining how these patterns of collaboration were affected by the organizational subculture of the police ([28], pp. 31-36). These approaches have contributed important concepts and knowledge about law and police at the border of the state. However, despite one recent framework being developed to study internationalized criminalization across different crimes [29], previous scholarship has understudied how the shared national roots of international and transnational criminal justice practitioners was written into the bifurcation of these two fields.

To conduct a critical, sociological investigation of the links between the two disjointed fields of criminal law, each with their own vocabulary, a few conceptual clarifications are necessary. Following Weber, the present definition of international and transnational criminal justice takes enforcement, and in particular the professionals that dominate this enforcement, as its core object. In doing so, it does not claim that these two fields are entirely distinct legally or practically, but that their enforcement systems are dominated by different elites. The article uses the term criminal justice rather than criminal law precisely to underline the role of enforcement professionals for the sociological analysis. To cut across the two spaces, the article at times uses the term extra-national criminal justice to cover all forms of regulations and practices that are not strictly national. The term covers both international and transnational criminal justice. Different extra-national criminal justice initiatives are characterized by having divergent relations to the state, as is embodied in the elites of the two studied fields.

To enable a critical analysis of how national power dynamics were written into the social structures, and to some extent activated in the political developments, of extra-national criminal justice, the article is inspired by the sociology of Pierre Bourdieu, in particular his interconnected concepts of capital and field [30]. Capital is understood here as the professional expertise embodied in the careers of the studied professionals. Building most of this capital in proximity to the state (its system of education and criminal justice bureaucracy), the careers and habitus of criminal justice professionals is indicative of their position, prestige and power in the state apparatus, for instance proximity to or distance from political/diplomatic power. Legal and police agents bear this capital with them when they move into institutions at the border of the state. Critically studying the professionals that populated international and transitional justice institutions allows the analysis to debunk the types of state structured professional capital involved in their development, how different types of capital were invested at the border of the state.

Bourdieu's field concept has previously inspired analyses of international criminal justice [31-33] and transnational crime control [34, 35]. A field is characterized by the relational positions active in it, and by the contest to define the principle of 
legitimate and legitimating domination in this social space, a contest that is based on the capital of agents in the field [30]. In other words, in national fields, as well as those created at the boundary between states, elites compete to define who should be in charge and what principle (or ideology) should organize and legitimate this pattern of domination. Building on these concepts, scholars have analyzed how battles between national elites affected the import and export of legal (and economic) ideas and practices [36], and how national spaces have different conceptions of the meaning and direction that new legal frameworks ought to take [37]. In the present analysis, the struggle to define international and transnational criminal justice is rooted in the national positionalities of elites active in these fields. Reproducing this position through their nationally formatted accumulation of capital, these elites invested different types and volumes of expertise at the border of the state. The different positions of legal and police professionals were reproduced, but exacerbated at this border where the two elites dominated distinct fields.

\section{Data and positionality of the two groups}

The empirical data on which the article relies is composed of 207 career biographies of elite professionals involved in the development of extra-national criminal justice enforcement. The diachronic data was designed to capture different waves of development in the fields of international and transnational criminal justice from the interwar period to transformations after the end of the Cold War. The sampled professionals come from either international criminal courts that deal with the so called core crimes, or institutions working with police and prosecutorial cooperation on crime more broadly. The former were dominated by legal professionals while the latter were dominated by police professionals, but populated also by legal professionals with narrow criminal law expertise. The institutions in which these professionals worked were, mostly, created as a result of political processes. But as the negotiating history and development of these institutions show, the politically defined functions of these institutions are not innate. Relational and competitive, these functions are constantly developed and renegotiated through the practices of the professionals active in them that, in some cases, helped define their contours in the first place.

The sampling of professional profiles aimed to produce a temporally sensitive collective biography ([38], pp. 9-11) of professionals involved in international and transnational criminal justice. Professional profiles were produced on the basis of publically available information on agents working in specific institutions. The material was collected from online and written sources in the autumn of 2019 and spring of 2020, and was organized in a format that made different biographies comparable. The format highlighted the experience of professionals in domestic systems as well as how and when they moved into positions at the border of the state. Having identified the forms of expertise prevalent in the sampled professionals, the format of the collected biographies grouped experience that was either related to practical criminal justice work (often in the police or prosecution), to diplomatic expertise (for instance, agents being part of negotiating treaties on extra-national crime) and 
finally academic capital (professorships etc.). This allows for direct comparisons of the groups studied and of the forms of capital they had accumulated in national and extra-national settings. The biographies had two coders to enhance reliability and validity. On the basis of this material, descriptive statistics on the collective accumulation of capital in the studied groups was developed (presented in more detail below).

From the field of international criminal law, biographies were sampled from the interwar and post-war attempts to create an international criminal court (commission of responsibility in 1919, preparation for the 1937 criminal court $(n=35)$. In addition, professionals were sampled from Nuremberg $(n=22)$ as well as the judges from the ICC that began operations in $2003(n=48)$. In the latter case, only judges have been included in the material, while the earlier material includes judges as well as other legal professionals who worked to develop these institutions. From transnational police and criminal justice cooperation, data on the former and current presidents and secretary-generals of Interpol was collected $(n=22)$ as was data on the police officials currently active in Europol $(n=52)$ as well as legal professionals in Eurojust $(n=28)$. These institutions are very different, Interpol having a near global membership, whereas the latter institutions are regional and confined to the context of the EU. These EU institutions were included due to their pioneering role in European criminal justice cooperation on the side of police and the prosecution. This also allows investigation of the balances of professional power between law and police in a concrete regional setting of a European space of justice and security.

The sampled professionals come from very different national systems in which the two types of elites that ended up in extra-national institutions had built their primary expertise. Focused on the similar position and accumulation of capital of law and police professionals, the analysis is not able to investigate in depth the particular national dynamics of power that affect patterns of accumulation of expertise in different criminal justice systems. In national systems, legal and police professionals worked closely together, but developed different patterns of capital. Moving into institutions at the border of the state, they carried their state-built capital with them and, at times, used it to support particular solutions beyond the state. International and transnational criminal justice were developed in relation to different professional groups that moved from the state machinery to shape enforcement beyond the state. In certain extra-national contexts, these professionals still acted as the representatives of their states, for instance in diplomatic negotiations of new legal frameworks. In other contexts, for instance when they served as international judges, they were elected at the behest of their state, but were expected to fulfil their role as independent of said state [39-42].

A few concrete examples can demonstrate how the bifurcation of international and transnational criminal justice was rooted in professionals who had a parallel socio-genesis in national systems. For instance, German nationals Bertram Schmitt (born 1958) current judge at the ICC, and the Secretary-General of Interpol, Jürgen Stock (born 1959), came from the same system, but ended up in international and transnational criminal justice respectively. Before joining the ICC, Schmitt worked in the court system in the German Bundesstaat of Hesse (where Stock also worked). Schmitt was promoted to presiding judge in the Regional Court in Darmstadt, 
working with juvenile and criminal cases, before being promoted again to judge at the Federal Court of Justice (2005). In 2009 he was appointed to Joint Supervisory Board of Eurojust and ad-hoc judge at the European Court of Human Rights, before being elected onto the ICC bench in 2015. The career of Stock took a different route, characterized by a more narrow accumulation of expertise and higher degree of specialization, having worked as a police officer in Hesse before pursuing his law degree (final state exam in 1995). Stock moved to the national level and became Deputy Head of Section at the Bundeskriminalamt, specialized in economic crime, and then became Vice-President in the same institution in 2005. Having served as European Delegate on the Executive Committee of Interpol since 2006, Stock became Secretary-General of this institution in 2014.

Despite the many differences between national justice systems and the role and power balance of criminal law and police within them, similar dynamics are visible in other countries. The South Korean judge elected to the ICC in 2015, Chung Chang-ho (born 1967), for instance, moved up in the judicial system before becoming High Court Judge in 2010 and a judge in the Extraordinary Chambers in the Courts of Cambodia (ECCC) in 2011, moving to the permanent court a couple of years after. Interpol President (2018-2020), Kim Jong Yang (born 1961), worked his way up the ranks in the Korean police force and was Director General for Seoul before making Director General of the Foreign Affairs Bureau in the national police force in 2011, joining Interpol's Executive Board in 2012. As these examples illustrate, legal and police professionals often worked in the same justice and criminal justice systems, but had distinct positions in the national field. The legal professionals that would later staff international criminal justice institutions often worked not only with criminal law and consequently accumulated broader expertise in relation to the state, including its academic and political institutions. This accumulation of expertise follows established patterns of power and prestige in which legal education was often placed at universities, while police training frequently took place at police academies or at other professional schools. Returning to Weber's sociological definition of (criminal) law as defined by the existence of professionals tasked with enforcement, legal and police professionals embodied distinct elements of this enforcement system that they carried with them into extra-national criminal justice.

To make intelligible the different forms of expertise accumulated by these elites, three species of career capital were identified and used to code the biographical material. These species were practical, academic, and political expertise, dimensions identified through previous fieldwork in the two fields [43, 44] and corroborated by the data built for the article. In order to identify the relative distribution of career experience across the three species, each of the collected career biographies were coded for whether or not the individual had been employed within practice, academia, and/or politics. Each individual was given one point for professional positions in either academia, legal/police practice or politics (most often diplomacy, but also as ministers etc.). The relative differences in distribution and volume of career experience within the different sampled groups is used to investigate their positionality within national systems and how it formatted the bifurcation of the two fields outside the nation state. In addition to the coding of the career profiles, the analysis builds on a qualitative analysis of these trajectories used to exemplify characteristics 
typical of different social groups. The differences between the accumulated capital of the two groups are clearly visible in Fig. 1 below.

Depicted here across the three species, the figure reveals a crucial difference in the accumulation of capital of the two groups (here aggregated across the different time periods). In the case of professionals involved in international criminal justice (most of whom had a law degree), the collective capital of this group was built at the crossroads of the three species of capital. In contrast, transnational criminal justice professionals (most of whom were trained police, but some holding a law degree) exhibit a very different pattern of accumulated capital. This group almost exclusively built practical, criminal law expertise, accumulating little political and very little academic capital. This accumulation was linked to the professional structure and division of labor of national fields of criminal justice to which these professionals were tied and where they spent a considerable part of their careers.

The embodied capital had both structural and structuring effects. On the one hand, the capital in the two groups was a structural effect of the national field and the reproduction of its valuation of different professions within it. As such, the capital inscribed into the different groups mirrors their position in the national, from its educational system to its justice system. On the other hand, the accumulation of capital had structuring effects that formatted the ability of these groups and their individuals to mobilize different forms of power. For instance, the accumulation of political and academic capital testifies to a social standing that allowed agents to enter these arenas and, under the right circumstances, use this access to affect the development of law and justice institutions. As such, the capital of a certain group had effects on what it could do and, as a consequence, on the strategies its professionals were likely to adopt. It is also likely to affect the conceptual schemes embodied in distinct groups of professionals and the norms they promote.

As evidenced in the career trajectories, agents in international criminal law and transnational policing have often been joined at the professional hip in their national
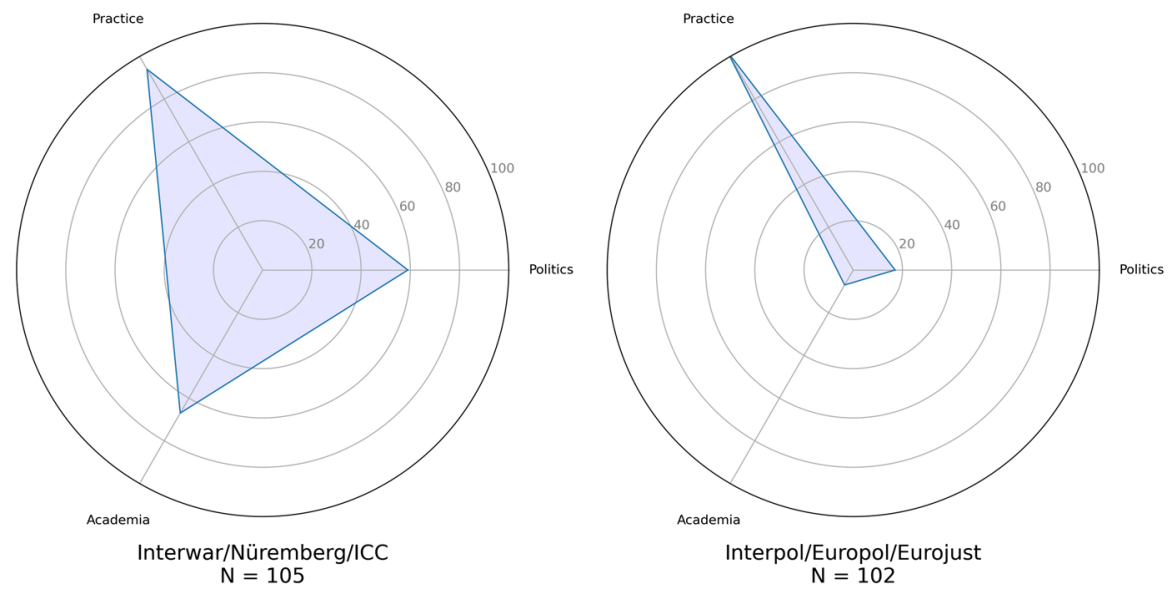

Fig. 1 The collective accumulation of capital in international criminal justice and transnational criminal justice professionals 
context. Examining the profiles active in extra-national criminal justice reveals their common origin in national systems, but also how they were separated by different educational backgrounds (law and police) as well as by distinct patterns of capital accumulation. Access to building different types of expertise was not equally divided, but linked to hierarchies in educational background (and at a deeper sociological level likely to generational strategies of reproducing status and capital) that typically mediated parameters of entry into different parts of the justice system from where distinct forms of expertise could be built. It is on the basis, and closer analyses of the individual and collective biographies on which they build, that the article investigates the social fabric that was embedded in and affected the bifurcation of law and police at the border of the state.

\section{Lawyers and international criminal law}

The three subsamples of professionals active in international criminal justice cover a span of almost 100 years and four different institutions or attempts at creating institutions (at Versailles, the 1937 court, Nuremberg and the ICC). However, despite their differences, the agents active in the development of this field generally built their professional engagement at the intersection between law, academia and diplomacy (see Fig. 2 below). The collective constitution of the studied elite exhibits diachronic variation, but overall, and compared to police professionals, retained a reliance on and ability to mobilize different forms of capital.

Over time, the relative political capital of the elite of international criminal justice decreased. Between the interwar era and Nuremberg, this decline was likely linked to the critique of the dominance of vocational nobility in diplomacy [45] that was given partial blame for the outbreak of WWI ([46], pp. 187-189). This led to reforms of diplomatic services that were professionalized around legal ideals and agents ([47], pp. 17-20), but also staffed with other professional groups such as social scientists ([48], pp. 113-126). This professionalization developed in parallel to the bureaucratization of other civil service branches identified by Weber [49] that resulted in the differentiation of diplomacy from other, increasingly autonomous,
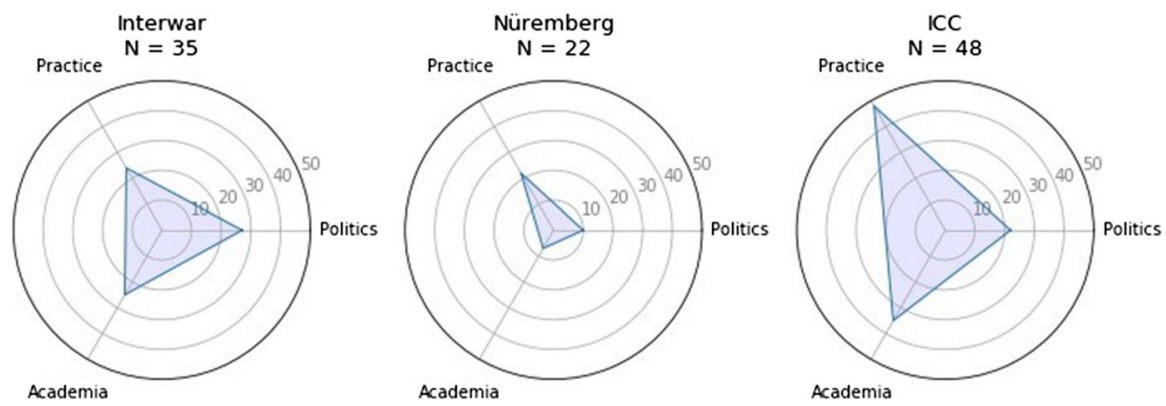

Fig. 2 The collective accumulation of capital across international criminal justice institutions 
state domains. Besides being characterized by legal agents, this professionalized diplomacy relied also on specialized (legal) expertise that was called into service when needed, but was separated from the inner sanctums of state politics and power. Professors of criminal and international criminal law at times occupied such positions that allowed them to affect state diplomacies in concrete processes of negotiation.

The career profiles of interwar international criminal lawyers were deeply integrated in the practical, academic and political life of their state. Activating this capital, these jurisconsults helped create the contours of international criminal law from professional roles that allowed mobilization across different, in this constellation mutually supportive, forms of expertise. Building on this capital and the different positions in social space it gave access to, the earliest proponents of an international criminal court often organized in professional associations that pushed for specific solutions. For instance, the International Law Association, through the vocal support of Hugh H. L. Bellot, promoted the idea of an international criminal court as part of a wider endeavor to ensure 'internationalism through law' [96]. Emblematic for the interwar group, Bellot was an Oxford graduate, UK barrister, and had served on diplomatic missions including the inquiry into Breaches of the Law of War after WWI. He had also been professor of constitutional law at the University of London. Another example of transnational mobilization that pushed for internationalized solutions was the International Association of Criminal Law (AIDP) driven by names such as Henri Donnedieu de Vabres, Vespasian Pella, and Emil Stanisław Rappaport (each of whom contributed seminal works to the nascent discipline [50-52]. The association focused on the theoretical and practical development of international penal law by: 'realizing an ideal of a universal penal law, and a coordination of its practical administration' as its constitution article 1 subsection 3 read [95]. The ADIP advocated the creation of an international criminal court to work 'against the dogma of state sovereignty' [53]. Several members of the organization also served as state representatives to the League of Nations. Rappaport penned the convention that established, if only on paper, the first international criminal court created to deal with terrorism in 1937 [54].

At and after Nuremberg several of the active legal experts had roots in the interwar era, de Vabres serving as French judge and Pella writing an influential memorandum on a permanent international criminal court in the postwar period [55]. In addition, Nuremberg built on some of the frameworks and networks developed between the two world wars and promoted by interwar professionals and their successors. Raphael Lemkin [56], who coined the concept of 'genocide' that he fought to include in the trials (after being pushed out of the US team at Nuremberg) had worked closely with Rappaport in Warsaw before the war. Hersch Lauterpacht, who coined the influential concept of 'crimes against humanity', was a student of Hans Kelsen, who worked as legal advisor for the United Nations War Crimes Commission in Washington, D.C, during WWII [57]. Whereas both Lemkin and Lauterpacht are now celebrated as founding fathers of the discipline [58-61], access to the diplomacy around Nuremberg was not a given for either of these agents. They were invited into the diplomatic process when it was deemed politically opportune. This position at the border to diplomacy was related to the professionalization of this branch of government that 
occurred after WWI. In some cases, the legal characteristics of reformed diplomacies still allowed elites who had built broad professional capital in state systems to carry their ideas into negotiations, although they would not always be used.

The use of internationalized criminal law as an enforcement mechanism pioneered at Nuremberg [62] was not continued at the international level during the Cold War, but its conceptual innovations were reproduced and tied to the construction of a professional ethos around international criminal justice as related to a specific professional group [63]. Before the surge of international criminal justice after the end of the Cold War, divorced from having direct enforcement impact, international criminal law expertise became a primarily academic endeavor that was propagated ideologically and conceptually in small networks built, for instance, around the AIDP. One example is the Vespasian V. Pella medal, first given to Nuremberg prosecutor Ben Ferencz in 1958, passed onto Cherif Bassiouni in 2000, Bassiouni handing the medal over to academic William Schabas in 2010. The three recipients of the prize all played important roles in the resurgence of international criminal justice after the end of the Cold War, working across academia, diplomacy and practice, and embodied three different periods: Nuremberg, academic reproduction of international criminal law ideas and finally the resurgence of international criminal justice as an ideology and practice. They also exemplify an accumulation of different types of capital still visible in the elite of this field. This pattern was reproduced in the judges of the ICC. Judges at this court had built both practical, academic and high degrees of political capital that enabled them to be diplomatically relevant and to serve as experts in political negotiations when called upon. For instance, current Canadian judge at the ICC, Kimberly Prost, was part of her national team of negotiators at the Rome Conference when the Statute of the ICC was passed in July 1998. Current French judge, Marc Perrin de Brichambaut, lead his national delegation at the same conference.

The legal elite involved in this diplomacy was much more global than that of the postwar period and includes agents from the global south that emerged as a diplomatic force after independence from colonialism beginning in the 1960s [64, 65]. Despite massive differences between north and south societies, elites from the south structurally resembled those of their former colonizers in terms of their accumulation of capital and position within the state. They became part of a global elite able to access and cater to diplomacy in and around their own countries. For these elite professionals, this interstitial role was structured by national fields of power in which some legal professionals had access to high-level positions across the three species of capital. At the crossroads of working in the national criminal justice systems of the state, in academia and advising diplomacy, elite professionals were able to affect, at certain critical junctures, the policies of the state. It was on the basis of this interstitial professional habitus that elite professionals helped build an international bureaucracy that they often became parts of themselves, in the process leaving the national system to become employed in the international criminal courts. The enforcement system they helped build was monopolized, or at least dominated, by legal professionals. These professionals held the highest positions in a field that has been referred to as a weak field due to its reliance on but distance from politics and consequent lack of autonomy [66]. At the border of the state, this international, 
lawyerly enforcement system constantly interacted, and sometimes conflicted with, national diplomacies and justice systems that they rely for effective enforcement $[67,68]$. Whereas not always successful in their negotiations to ascertain support for investigations, arrests or cooperation, the capital of the international criminal justice elite was attuned to engage in such diplomatic battles between internationalized criminal courts and states. However, whereas they had worked in proximity to diplomacies, they now represented internationalized criminal courts and were often perceived with skepticism in states including those in which these institutions intervened and, very often, those that they appealed to for assistance.

In advocating the internationalization of criminal law this professional elite followed patterns of thinking that were structured by an overlap between their accumulated capital and their perception of the value of international solutions. The language of international diplomacy was written into the socio-professional composition of this group, just as they attempted to write their language of international (criminal) justice into the fabric of diplomacy. They were able to play this game because they spoke international. On the basis of this habitus, the international criminal justice elite helped build a field dominated by lawyers with similar profiles, reacting to and influencing the preferences of the state that they had access to at different points. The sociological makeup of the international criminal law elite seems to have marginalized or devalued other forms of professional capital, including policing. The courts have been criticized for their reluctance to hire police officers even for positions in investigative units ([69], p. 2). This monopolization (and resulting patterns of marginalization) was driven by a field of criminal justice that identifies and understands itself primarily as a legal endeavor.

\section{Police and transnational criminal justice}

The first well-known efforts to create an international police conceptualized such a force as a form of military power, a global constabulary that had minor elements of traditional police functions [70]. In the beginning of the $20^{\text {th }}$ century one promotion of an international police force was driven by Theodor Roosevelt in an attempt to ensure global US influence [4]. Another was championed by Welch politician Lord Davies as a militarized organization that could uphold the law of the international community that emerged after WWI [71]. These attempts were not successful. The Cold War era did saw the creation of a range of legal frameworks designed to curb different forms of transnational crime but left enforcement to states [8]. The development of such frameworks accelerated after the Cold War, for instance with the UN Convention against Transnational Organized Crime or the UN Convention against Corruption. Inspired again by the insights of Weber, this section investigates the sociological fabric of this field and the professionals dominant in its enforcement activities.

The militarized conceptions of an international police, typically formulated by lawyers or politicians, coexisted with more transnational efforts to create new forms of communication and cooperation between national police forces. In contrast to 
efforts of internationalizing criminal justice enforcement of core crimes, new modes of cooperation and institutions to support criminal justice responses were developed in particular by police managers or specialists of criminal law. Transnational forms of police developed, at least initially, outside of the flow of more standardized and formal diplomatic channels of, for instance, foreign ministries. In addition, initiatives were also often developed without a supportive academic architecture that characterized pushes for internationalization of criminal law. This is indicated in the data on career trajectories of core agents in and around the main institutions of police (and in the case of Eurojust, prosecutorial) cooperation created since the interwar era (see Fig. 3 below).

This collective accumulation of capital in the group of transnational criminal justice professionals was structured by the position of police and security professionals (that included lawyers, but in this case lawyers with mainly practical, criminal law expertise) in state justice systems. This position formatted their access to state power and their ability to affect the preference of the state with regard to extra-national initiatives and forms of cooperation. Unlike legal professionals with broad accumulation of capital across practice, academia and diplomacy that were frequently called in to serve as experts of the state, police and security officials had little access to diplomatic circles and typically served instead as bureaucrats tasked with operational enforcement aspects of criminal justice.

This professional habitus is visible in one of the first important developments in the field of transnational criminal justice. The establishment of Interpol built on earlier ideas generated for instance in the Police Union of German States [72]. Interpol was revived in 1923, by Johannes Schober, as the International Criminal Police Commission (ICPC, later Interpol [73, 74]). Linked to contemporary perceptions of crime, the name of the commission underlined the investigative and operational nature of this endeavor that was also linked to the birth of new forensic technologies [75]. A trained lawyer and politician, Schrober's career profile was characterized by both practical expertise with the police and significant political experience, serving for two periods as Chancellor of Austria, at times holding other ministerial posts. This access to politics was the exception to the rule in the group of professionals active in transnational criminal justice. Later development of Interpol built on the direct participation of police officials ([76], pp. 752-754), police cooperation across
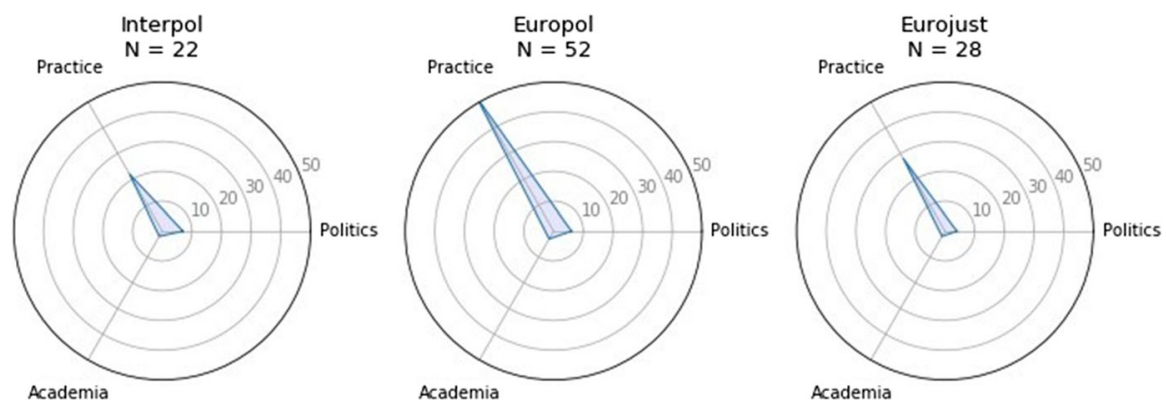

Fig. 3 The collective accumulation of capital across transnational criminal justice institutions 
states having developed incrementally since the mid-1800s ([77], pp. 151-236). In Deflem's analysis, such early transnational practices (preceding decolonization) built on the autonomization of police forces in the national context [76]. This development coexisted with the differentiation of state bureaucracies, including diplomacy, that occurred in the interwar period. These early innovations of transnational police cooperation typically included global north police forces, but police technologies were often tested first in colonial contexts [78, 79], and countries in the south maintained police forces after independence. Different in their forms of organization and serving different political systems, the existence of police forces with authority to use force was comparable across different states. This is reflected in Interpol that has a membership of 194 states, more than the current 193 states represented in the UN General Assembly.

The national position of policing, reflected in the accumulated capital of its elite, meant that extra-national activities and ambitions took different paths than was the case for international criminal law. This was the case in the interwar period as well as after the end of the Cold War. From the 1990s transnational police cooperation was seen both as a response to new forms of crime and as a potential challenge to the monopoly of state power ([80], pp. 1-18). Extra-national police practices had to mediate this dilemma, while at the same time producing answers to political problems that police forces themselves helped define and put on the agenda. Within the EU (that has so far taken the lead in terms of regional police cooperation, although other regional initiatives exist [81], transnationally organized police forces successfully helped set the agenda for security policies in the region. One initiative was TREVI [82, 83]. The group was set up in 1975 by interior and justice ministers from the European Community (EC) as an intergovernmental endeavor to coordinate the fight against terrorism. The work of TREVI had three layers of cooperation (ministerial, TREVI senior officials, and working parties such as ministry officials, police officers, security services).) However, whereas TREVI formally cut across different professional groups, most activity took place at the level of actual police officials involved in the day-to-day work of their national criminal justice system. It was also from these working groups that the preparations for what became Europol sprang ([82], p. 3). As such the practical orientation of professional activity in the TREVI group was exemplary for the incremental development of a field of security agencies aimed at enhancing police cooperation in the EC (and later the EU [34, 84]).

In wider EU space of security cooperation, organizations that deal with security are driven and dominated by police officials who were part of what Didier Bigo has called 'transnational guilds' [85, 86]. In Europol, the police officers seconded to the organization are part of the national police bureaucracy, often specialists of intelligence gathering, investigation and detective work in their own jurisdiction. The profiles of the staff at Europol can be seen in the Management Board of the organization, national members holding strong police credentials but had typically not accumulated significant volume of other types of expertise. Many had operational experience from transnational cooperation in different contexts and had specialized in specific crime problems in their national jurisdictions many of which also were the object of Europol activities and reporting (terrorism, organized crime, financial crime, anti-mafia etc.). As such, they were repeat players in the emerging European 
field of police and security and often participated in expert networks, but often those under the domain of ministries of justice or the interior, typically not related to the foreign services.

Something similar is the case for the legal professionals working in Eurojust [35]. Despite having law degrees and access to high positions in the national criminal law bureaucracy (but not the highest positions as was the case with generalist judges), agents in Europol had limited diplomatic expertise. In contrast to the legal professionals active in international criminal justice whose legal expertise was often broad and expanded beyond criminal law, Eurojust agents were more likely to have accumulated expertise specifically from criminal justice activities. They were specialists in criminal law and not legal generalists. This group of law professionals was also weaker in the EU system of criminal justice. Both Eurojust and Europol became supranational institutions with the Lisbon Treaty. In the EU security field, Europol has become the dominant organization with about 1.300 employees, compared with about 320 in Eurojust, the budget of the former being 130 million Euro (and rising) against the latter's 38 million Euro in 2018 (a number that has stagnated in recent years). Europol also hosts important databases in which national police can search for information. Due to this role, Europol has had most impact in relation to setting the agenda for security in the context of the EU. Whereas Eurojust has been able to construct a stronger operational position for itself in the context of Joint Investigation Teams (or JITs [87]), it is the operational practices and intelligence-driven analysis of Europol that dominates transnational security cooperation within the EU.

The balance of power between the Europol and Eurojust, in which the transnational activities of the police forces have to a large degree subjugated the activities of legal professionals, has parallels in a more global setting. Global policing, or transnational policing networks, crisscross different regions and tie them together through diverse forms of cooperation [28, 88, 89], for instance in specialized networks formed to deal with drug trafficking or terrorism [80, 90, 91]. Due to their operational position within national systems of criminal justice, police officials work transnationally to construct forms of cooperation that built professional power without explicitly activating diplomatic expertise linked to the ability to access policy building in the state in which they were employed. These processes mirrored their structural position in the state where police professionals accumulated mainly practical experience outside of diplomacies and academia. These structurations (reflected both in the position of police and their accumulation of capital) formatted how policing was pushed to the borders of the state. Here forms of cooperation were often politicized and institutionalized ex post facto, developed through the investments of police professionals into operational networks.

\section{Conclusion}

As law and police were pushed to the border of the state, international and transnational criminal justice took different paths. Beginning in the interwar period, this bifurcation was linked to the wider differentiation and autonomization of state (sub)systems in an era that saw the expansion and solidification of the state. 
The positionality of law and police in the national criminal justice system that crystalized in this period has been reproduced over time, as indicated in the accumulation of capital of elites studied in this article. As a sociological phenomenon, the bifurcation of international and transnational criminal justice was built into and partly driven by the career trajectories of elites active in these fields. In other words, the bifurcation of law and police mirrored social and professional differentiations embedded in and affected by power balances in and of the state, in particular in relation to its justice and criminal justice systems. Some legal professionals had accumulated capital in close proximity to broad legal practices as well as to state diplomacies and academia that allowed them to participate in (and promote) the internationalization of criminal justice. On the other hand, police professionals (and legal professionals working mostly in criminal justice systems) mainly had practical expertise related to criminal justice enforcement and built transnational cooperation outside of established channels of diplomacy. The national division of labor embedded in these profiles was invested into what became two disjointed fields of practice. Each of these fields has been developed through the activity of distinct groups of professionals that helped shape them in their image, both practically and in terms of universalizing the principle of domination that allows them to reproduce their monopoly. This image was structured by their accumulation of capital and relation to the state.

Reconnected to their national provenance, the professionals working in the two fields appear as twinned elites, the distance between which enhanced as they deployed their capital to help develop criminal justice at the border of the state, building in the process powerful positions from themselves either as public figures of international criminal justice or the hidden agents behind transnational police and security. Conceptualizing these fields as linked through the provenance of their elites opens new avenues for future research. Such studies could, for instance, investigate the monopolizing effects of such spaces as linked to specific professional groups, including how elites from different countries and regions have been woven into these larger structures, and how this engagement differs over time depending, for instance, on the dominance of specific national professionals. This would require deeper analyses of individual national systems, in particular how agents of law and police are related to state fields of power and how these agents have attempted to extrapolate their career capital to affect international and transnational criminal justice or other initiatives aimed at curbing serious criminality. Recoupling criminal law and police beyond the state can provide crucial insights into how these spaces developed, function and have effects. In addition to effects on international and transnational criminal justice, the power dynamics between law and police at the border of the state might also affect initiatives and activities where the two groups work closely together.

Investigating the position of elites at the national origin of their professional capital could also lead to new studies of the ways international and transnational criminal justice works as enforcement systems. Some of the main criticisms levelled against the two fields can be seen as mirror images of their professional makeup. Linked to their lack of access to police power, international criminal justice, for instance, has been criticized repeatedly for not being able to build solid evidence 
[92], something that has led to the creation of new institutions [93] typically staffed at the top by lawyers with experience from the field, supported by different types of investigators. Transnational police collaboration, in contrast, has been criticized for being developed outside of democratic control and for negatively affecting liberal freedoms [94]. Analyzing the two fields in conjunction, these endemic criticisms stand out as field effects linked to and affected by the disjunction that created two separate enforcement systems dominated by either law or police. Although it has never been complete and the lines between the two fields overlap, this bifurcation has been routinized and is reproduced in the capital of its professionals. It has also been naturalized and conventionalized in scholarly and political perceptions to the point where it is, at times, taken for granted. Breaking free from this perception can reconnect the professionals who helped develop these fields to the state-built capital that allowed some of them to directly influence international diplomacy and led others onto alternate routes to transnational influence.

Acknowledgement of funding This project has received funding from the European Research Council (ERC) under the European Union's Horizon 2020 research and innovation programme (JustSites: StG-802053)

Open Access This article is licensed under a Creative Commons Attribution 4.0 International License, which permits use, sharing, adaptation, distribution and reproduction in any medium or format, as long as you give appropriate credit to the original author(s) and the source, provide a link to the Creative Commons licence, and indicate if changes were made. The images or other third party material in this article are included in the article's Creative Commons licence, unless indicated otherwise in a credit line to the material. If material is not included in the article's Creative Commons licence and your intended use is not permitted by statutory regulation or exceeds the permitted use, you will need to obtain permission directly from the copyright holder. To view a copy of this licence, visit http://creativecommons.org/licen ses/by/4.0/.

\section{References}

1. Aas, K. F. (2007). Globalization \& Crime. Los Angeles: Sage Publications.

2. Boister, N. (2003). Transnational Criminal Law? European Journal of International Law, 14(5), 953-976.

3. Christensen, M. J., \& Levi, R. (2017). Introduction: An Internationalized Criminal Justice: In Mikkel Jarle Christensen \& Ron Levi (Eds.), Paths of Law and Paths of Police' in International Practices of Criminal. London: Routledge

4. Levi, R., \& Hagan, J. (2006). International Police. In M. D. Dubber \& M. Valverde (Eds.), The New Police Science: The Police Power in Domestic and International Govenance. (pp. 207-247). Stanford: Stanford University Press.

5. Weber, M. (1968). Economy and society, an outline of interpretive sociology. New York: Bedminster.

6. Kjeldgaard-Pedersen, A. (2015). What Defines an International Criminal Court?: A Critical Assessment of 'the Involvement of the International Community' as a Deciding Factor. Leiden Journal of International Law, 28(1), 113-131. https://doi.org/10.1017/S0922156514000569

7. Stahn, C. (2018). A Critical Introduction to International Criminal Law: Cambridge University Press.

8. Boister, N. (2012). An Introduction to Transnational Criminal Law. Oxford: Oxford University Press.

9. Christensen, M. J., \& Boister, N. (2018). New Perspectives on the Structure of Transnational Criminal Law. Brill Research Perspectives in Transnational Crime. 
10. Lewis, M. (2014). The Birth of the New Justice: The Internationalization of Crime and Punishment, 1919-1950. Oxford: Oxford University Press.

11. Boister, N. (1998). The Exclusion of Treaty Crimes from the Jurisdiction of the Proposed International Criminal Court: Law, Pragmatism. Politics. J. Armed Conflict L., 3, 27

12. Kreß, C. (2018). On the Activation of ICC Jurisdiction over the Crime of Aggression. In The Rome Statute of the ICC at Its Twentieth Anniversary (pp. 43-64): Brill Nijhoff.

13. Boister, N. (2012). International Tribunals for Transnational Crimes: Towards a Transnational Criminal Court? Criminal Law Forum, 23(4), 295-318. https://doi.org/10.1007/s10609-012-9182-4

14. Paulose, R. M. (2012). Beyond the core: incorporating transnational crimes into the Rome statute. Cardozo Journal of International \& Comparative Law, 21(1), 77-109

15. Christensen, M. J., (2017). Crafting and Promoting International Crimes: A Controversy among Professionals of Core-Crimes and Anti-Corruption' Leiden. Journal of International Law 30(2), 501-521

16. Kotiswaran, P., \& Palmer, N. (2015). Rethinking the 'international law of crime': provocations from transnational legal studies. Transnational Legal Theory, 6(1), 55-88

17. Mégret, F. (2020). The Unity of International Criminal Law. In K. J. Heller, F. Mégret, S. Nouwen, J. Ohlin, \& D. Robinson (Eds.), The Oxford Handbook of International Criminal Law. Oxford: Oxford University Press.

18. Van Der Wilt, H., \& Paulussen, C. (2017). Legal responses to transnational and international crimes: towards an integrative approach? In Legal Responses to Transnational and International Crimes: Edward Elgar Publishing.

19. OTP, O. o. t. P. (2015). Strategic Plan 2016-2018. Retrieved from The Hague:

20. Interpol. (2020). Crimes. Retrieved from https://www.interpol.int/en

21. Castells, M. (1999). The rise of the network society. Oxford: Blackwell Publishers.

22. Keck, M., \& Sikkink, K. (1999). Transnational advocacy networks in international and regional politics. International Social Science Journal, 51(1), 89-101

23. Glasius, M. (2006). The International Criminal Court: A Global Civil Society Achievement. New York: Routledge.

24. Sikkink, K. (2011). The Justice Cascade: How Human Rights Prosecutions are Changing World Politics. New York: W. W. Norton \& Co.

25. Nadelmann, E. A. (1990). Global prohibition regimes: the evolution of norms in international society. International Organization, 44(4), 479-526. https://doi.org/10.1017/S0020818300035384

26. Shaffer, G., \& Aaronson, E. (2020). Transnational Legal Ordering of Criminal Justice: Cambridge University Press.

27. Sheptycki, J. W. E. (Ed.). (2000). Issues in Transnational Policing. London: Routledge.

28. Bowling, B., \& Sheptycki, J. W. E. (Eds.). (2012). Global policing. Los Angeles, [Calif.] ; London: Los Angeles, Calif. ; London : SAGE.

29. Aaronson, E., \& Shaffer, G. (2020). Defining Crimes in a Global Age: Criminalization as a Transnational Legal Process. Law \& Social Inquiry, 1-32. https://doi.org/10.1017/lsi.2020.42

30. Bourdieu, P., \& Wacquant, L. (1992). An Invitation to Reflexive Sociology. Chicago: University of Chicago Press.

31. Dixon, P., \& Tenove, C. (2013). International Criminal Justice as a Transnational Field: Rules, Authority and Victims. International Journal of Transitional Justice, 7(3), 393-341. https://doi.org/ 10.1093/ijtj/ijt015

32. Hagan, J., \& Levi, R. (2005). Crimes of War and the Force of Law. Social Forces, 83(4), 1499-1534

33. Mégret, F. (2016). International Criminal Justice as a Juridical Field. Champ pénal/Penal field, 13.

34. Bigo, D. (2007). Mapping the Field of EU Internal Security Agencies. Paris: L'Harmattan.

35. Megie, A. (2007). Mapping the Actors of European Judicial Coorporation. In D. Bigo (Ed.), The Field of the EU Internal Security Agencies. Paris: L'Harmattan.

36. Dezalay, Y., \& Garth, B. G. (2002b). The Internationalization of Palace Wars: Lawyers, Economists, and the Contest to Transform Latin American States. Chicago: Chicago : University of Chicago Press.

37. Madsen, M. R. (2010). La genèse de l'Europe des droits de l'homme, enjeux juridiques et stratégies d'état, France, Grande-Bretagne et pays scandinaves, 1945-1970. Strasbourg: Strasbourg : Presses universitaires de Strasbourg.

38. Dezalay, Y., \& Garth, B. G. (2002a). The internationalization of palace wars, lawyers, economists, and the contest to transform Latin American states. Chicago: Chicago : University of Chicago Press.

39. Christensen, M. J. (2019). The Judiciary of International Criminal Law: Double Decline and Practical Turn. Journal of International Criminal Justice, 17, 537-555 
40. Madsen, M. R. (2018). Who Rules the World? The Educational Capital of the International Judiciary. UC Irvine Journal of International, Transnational, and Comparative Law, 3.

41. Powderly, J. (2020). Judges and the Making of International Criminal Law: BRILL.

42. Terris, D., Romano, C., \& Swigart, L. (2007). The international judge : an introduction to the men and women who decide the world's cases. Oxford ; New York: Oxford University Press.

43. Christensen, M. J. (2015). From symbolic surge to closing courts: The transformation of international criminal justice and its professional practices. International Journal of Law, Crime and Justice, 43(4), 609-625

44. Christensen, M. J. (2018). International Prosecution and National Bureaucracy: The Contest to Define International Practices within the Danish Prosecution Service. Law \& Social Inquiry.

45. Nightingale, R. T. (1930). The Personnel of the British Foreign Office and Diplomatic Service, 1851-1929. American Political Science Review, 24(2), 310-331. https://doi.org/10.2307/1946652

46. Black, J. (2010). A history of diplomacy: United Kingdom: Reaktion Books.

47. Constantinou, C. M., Cornago, N., \& McConnell, F. (2016). Transprofessional Diplomacy., 1(4), 1-66. https://doi.org/10.1163/24056006-12340005

48. Galtung, J., \& Holmboe Ruge, M. (1965). Patterns of Diplomacy. Journal of Peace Research, 2(2), 101. https://doi.org/10.1177/002234336500200201

49. Weber, M. (2007). Bureaucracy. In H. H. Gerth \& C. W. Mills (Eds.), From Max Weber: Essays in Sociology. (pp. 196-244). London: Routledge.

50. Pella, V. (1926). La criminalité collective des états et le droit pénal de l'avenir. Bucharest: L'Imprimerie de l'État.

51. Rappaport, E. S. (1929). Le problème de l'unification internationale du droit pénal. Varsovie,: "Revue pénitentiaire de Pologne".

52. De Vabres, H. D. (1922). Introduction à l'étude du droit pénal international; essai d'historie et de critique sur la compétence criminelle dans les rapports avec l'étranger. Paris: L. Tenin.

53. Pella, V. (1950). Towards an International Criminal Court. American Journal of International Law, 44, 37-68

54. Marston, G. (2003). Early attempts to suppress terrorism: The terrorism and international Criminal Court Conventions of 1937. The British Year Book of International Law, 73(1), 293.

55. Kuhn, A. K. (1952). The Pella Memoranda Relating to International Crimes and Criminal Jurisdiction. American Journal of International Law, 46(1), 129-130. https://doi.org/10.2307/2194639

56. Lemkin, R. (1944). Axis rule in occupied Europe, laws of occupation. Analysis of government. Proposals for redress. Washington: Washington : Carnegie Endownment for International Peace. Division of International Law.

57. Vrodoljak, A. F. (2010). Human Rights and Genocide: The Work of Lauterpacht and Lemkin in Modern International Law. The European Journal of International Law, 20(4), 1163-1194

58. Koskenniemi, M. (2004). Hersch Lauterpacht and the Development of International Criminal Law. Journal of International Criminal Justice, 2(3), 810-825. https://doi.org/10.1093/jicj/2.3.810

59. Mégret, F., \& Tallgren, I. (2020). The Dawn of a Discipline: International Criminal Justice and Its Early Exponents (F. Mégret \& I. Tallgren Eds.). Cambridge: Cambridge University Press.

60. Sands, P. (2016). East West Street : on the origins of "genocide" and "crimes against humanity" (First. (edition). New York: Alfred A. Knopf.

61. Schabas, W. A. (2000). Genocide in international law: the crimes of crimes: Cambridge University Press.

62. Heller, K. J. (2011). The Nuremberg Military Tribunals and the Origins of International Criminal Law. Oxford: Oxford University Press.

63. Kreß, C. (2014). Towards a Truly Universal Invisible College of International Criminal Lawyers. Torkel Opsahl Academic EPublisher Occasional Paper Series, 1-36.

64. Spies, Y. K. (2019). Global South perspectives on diplomacy: Springer.

65. Toye, J. (2014). Assessing the G77: 50 Years after UNCTAD and 40 Years after the NIEO. Third World Quarterly, 35(10), 1759-1774

66. Dezalay, S. (2017). Weakness as Routine in the Operations of the Intentional Criminal Court. International Criminal Law Review, 17(2), 281-301. https://doi.org/10.1163/15718123-01702004

67. Clark, P. (2018). Distant Justice: The Impact of the International Criminal Court on African Politics: Cambridge University Press.

68. Peskin, V. (2008). International Justice in Rwanda and the Balkans: Virtual Trials and the Struggle for State Cooperation. Cambridge: Cambridge University Press.

69. Cruvellier, T. (2012). Lessons from Lubanga trial. International Justice Tribune, 147, 2-3 
70. Bentham, J. (1927). Jeremy Bentham's Plan for an universal and perpetual peace. London,: Sweet \& Maxwell, limited.

71. Davies, D. (1932). An international police force: Ernest Benn.

72. Deflem, M. (1996). International Policing in Nineteenth-Century Europe: the Police Union of German States, 1851-1866. International Criminal Justice Review, 6(1), 36-57

73. Fijnaut, C. (1997). The International Criminal Police Commission and the Fight Against Communism, 1923-1945. In The Policing of Politics in the 20th Century. Oxford: Berghahn Books.

74. Jensen, R. B. (1981). The international anti-anarchist conference of 1898 and the origins of interpol. Journal of contemporary history, 16(2), 323-347.

75. Cole, S. A. (2001). Suspect identities a history of fingerprinting and criminal identification: Harvard University Press.

76. Deflem, M. (2000). Bureaucratization and social control: Historical foundations of international police cooperation. In Law Soc. Rev, 34, 739-778.

77. Liang, H.-H. (2002). The rise of modern police and the European state system from Metternich to the Second World War. Cambridge: Cambridge University Press.

78. Anderson, D. M., \& Killingray, D. (1991). Policing the Empire: Government, Authority, and Control, 1830-1940. Manchester: Manchester University Press.

79. Sinclair, G., \& Williams, C. A. (2007). 'Home and Away': The Cross-Fertilisation between 'Colonial' and 'British' Policing, 1921-85. The Journal of Imperial and Commonwealth History, 35(2), 221-238. https://doi.org/10.1080/03086530701337567

80. Friedrichs, J. r. (2008). Fighting Terrorism and Drugs : Europe and International Police Cooperation. London; New York: Routledge.

81. Betancourt, L., \& Facio, L. (2014). Cooperación policial entre Colombia y Centroamérica y el Caribe: El Crimen Organizado y el accionar de Ameripol bajo el enfoque multidimensional de la Seguridad Hemisférica. Memorias: revista digital de historia y arqueologia desde el Caribe(23), 1-24.

82. Bunyan, T. (1993). Trevi, Europol and the European state. Statewatching the new Europe, 1-15.

83. Fijnaut, C. (1992). Policing Western Europe: Interpol, Trevi and Europol. Police Studies: The International Review of Police Development, 15, 101

84. Anderson, M., Den Boer, M., Cullen, P., Gilmore, W., Raab, C., \& Walker, N. . (1995). Policing the European Union. Oxford: Clarendon.

85. Bigo, D. (2013). The transnational field of computerised exchange of information in police matters and its European guilds. In N. Kauppi \& M. R. Madsen (Eds.), Transnational Power Elites: The new professionals of governance, law and security. (pp. 155-182). London: Routledge.

86. Bigo, D. (2016). Sociology of Transnational Guilds. International Political Sociology, 10(4), 398416. https://doi.org/10.1093/ips/olw022

87. Helmberg, M. (2007). Eurojust and joint investigation teams: how Eurojust can support JITs. Paper presented at the ERA Forum.

88. Bowling, B. (2010). Policing the Caribbean: Transnational Security Cooperation in Practice. Oxford: Oxford University Press.

89. Goldsmith, A. J., \& Sheptycki, J. W. E. (2007). Crafting transnational policing : police capacitybuilding and global policing reform. Oxford: Hart Pub.

90. Deflem, M. (2006). Europol and the policing of international terrorism: counter-terrorism in a global perspective. Justice Quarterly, 23(3), 336-359

91. Deflem, M. (2010). The policing of terrorism: Organizational and global perspectives: Routledge.

92. Combs, N. A. (2010). Fact-Finding without Facts, The Uncertain Evidentiary Foundations of International Criminal Convictions. Cambridge: Cambridge University Press.

93. Mandel-Anthony, D. (2019). Hardwiring Accountability for Mass Atrocities. Drexel Law Review, 11(903).

94. Bigo, D. (2010). Delivering Liberty and Security? The Reframing of Freedom when Associated with Security. In D. Bigo, S. Carrera, E. Guild, \& R. B. J. Walker (Eds.), Europe's 21st Century Challenge: Delivering Liberty. (pp. 263-287). London: Ashgate.

95. AIDP. (1925). International Association of Penal Law. Journal of Criminal Law and Criminology, 15(4).

96. W. A, B. (1928). Hugh H. L. Bellot, D. C. L. Transactions of the Grotius Society, 14, xi-xiv

Publisher's Note Springer Nature remains neutral with regard to jurisdictional claims in published maps and institutional affiliations. 